\title{
PENGARUH TATA KELOLA PERUSAHAAN TERHADAP PENGUNGKAPAN TANGGUNG JAWAB SOSIAL DAN DAMPAKNYA PADA NILAI PERUSAHAAN
}

\author{
Arief Nurhandika, Amir Hamzah \\ Program Studi Akuntansi, Fakultas Ekonomi, \\ Universitas Kuningan, Jawa Barat \\ Email: amir.hamzah@uniku.ac.id \\ Email: anurhandika47@gmail.com
}

Diterima: November; Direvisi: 2 Desember 2019; dipublikasikan: 21 Desember 2019

\begin{abstract}
The Effect of Corporate Governance on Social Responsibility and its Impact on Firm Value. The purpose of this research was to determine the effect of Corporate Governance on Social Responsibility Disclosure, Social Responsibility Disclosure of Firm Value and the indirect effect of Corporate Governance on Firm Value through Social Responsibility Disclosure. This research was conducted at a Coal company listed on the Indonesia Stock Exchange in the period 2013-2018. The samples used were 55 samples. The statistical method used is the path analysis method with panel data regression. The results show that the Independent Board of Commissioners, Foreign Ownership, Public Share Ownership, and the Audit Committee has a positive effect on Social Responsibility Disclosure, Social Responsibility Disclosure has a positive influence on firm value, and the Independent Board of Commissioners, the Audit Committee does not have effect on firm value through disclosure of social responsibility, and Foreign Ownership, Public Ownership have an indirect effect on firm value through social responsibility.
\end{abstract}

Keywords: Corporate Governance, Social Responsibility, Firm Value

\begin{abstract}
ABSTRAK
Pengaruh Tata Kelola Perusahaan Terhadap Tanggung Jawab Sosial dan dampaknya pada nilai Perusahaan. Tujuan dilakukannya penelitian ini untuk mengetahui pengaruh Tata Kelola Perusahaan Terhadap Pengungkapan Tanggung Jawab Sosial, Pengungkapan Tanggung Jawab Sosial Terhadap Nilai Perusahaan dan pengaruh tidak langsung Tata Kelola Perusahaan pada Nilai Perusahaan melalui Pengungkapan Tanggung Jawab Sosial. Penelitian ini dilakukan pada perusahaan Batu Bara yang terdaftar di Bursa Efek Indonesia periode 2013-2018. Sampel yang digunakan sebanyak 55 sampel. Metode statistik yang digunakan adalah metode analisis jalur dengan regresi panel data. Hasil menunjukan Dewan Komisaris Independen, Kepemilikan Saham Asing, Kepemilikan Saham Publik dan Komite Audit memiliki pengaruh positif terhadap Pengungkapan Tanggung Jawab Sosial, Pengungkapan Tanggung Jawab Sosial memiliki pengaruh positif terhadap nilai perusahaan, dan secara langsung Dewan Komisaris Independen, Komite Audit tidak memiliki pengaruh langsung terhadap nilai perusahaan melalui pengungkapan tanggung jawab social dan Kepemilikan Saham Asing dan Kepemilikan Saham Publik berpengaruh langsung pada nilai perusahaan melalui tanggung jawab sosial.
\end{abstract}

Kata kunci : Tata Kelola Perusahaan, Tanggung Jawab Sosial, Nilai Perusahaan 


\section{PENDAHULUAN}

Dunia usaha menuntut perusahaan untuk memperoleh keuntungan sebagai tujuan akhir menjalankan aktivitas usahanya. Semakin banyaknya bermunculan perusahaan- perusahaan yang baru membuat dunia usaha tidak menutup kemungkinan menjadi ajang persaingan yang cukup ketat, sehingga perusahaan perlu memberikan fokus terhadap tata kelola sumber daya perusahaan agar aktivitas yang dilakukannya mampu dilaksanakan secara esisien dan efektif. Tata kelola perusahaan yang baik memberikan dampak positif kepada semua lini aktivitas perusahaan. Dampak yang cukup terdekat adalah kepedulian perusahaan dengan lingkungan sosial sekitar.

Perusahaan sebagai organisasi usaha tidak akan lepas dari permasalahan-permasalahan yang berkaitan dengan aspek sosial seperti pegawai yang menuntut kesejahteraan, pengolahan limbah perusahaan dan masalah yang menyangkut lingkungan sekitar perusahaan lainnya. Keterkaitan itu menyebabkan perusahaan dituntut untuk fokus kepada kepedulian lingkungan yang disebabkan oleh aktifitas yang dikeluarkannya berupa laporan tanggung jawab sosial. Menurut (Tommy, Utary, \& Oktavianti, 2015) faktanya perusahaan di Indonesia khusunya di sektor tambang yang setiap aktifitasnya tidak jauh dari keadaan lingkungan hidup masih belum fokus untuk peduli terhadap lingkungan sekitar atau kurang dalam memahami dan melaksanakan tanggung jawab sosial perusahaan.

Dewi \& Widagdo(2012) menyatakan bahwa perusahaan memiliki keterikatan dengan masyarakat sekitar sebagai satu lingkungan sosial yang menutut untuk terpenuhinya tanggung jawab sosial perusahaan sehingga dibutuhkanya penatakelolaan perusahaan yang baik. Menurut Maryanti \& Fithri(2017) tanggung jawab sosial perusahaan dan tata kelola perusahaan mampu memberikan peningkatan terhadap semua lini aktivitas perusahaan dan pandangan yang baik dari masyarakat.

Seiringnya waktu perusahaan mulai menyadari bahwa perlu adanya perubahan strategi bisnis yang dulu berfokus dalam mencari laba sebanyak mungkin akan tetapi sekarang perusahaan harus memberikan manfaat yang riil terhadap lingkungan karena setiap perusahaan menjalankan aktifitasnya akan bersinggungan dengan masyarakat sekitar.

Ketersediaan informasi yang cukup pada laporan keuangan adalah suatu kewajiban yang harus dilaksanakan oleh perusahaan karena dorongan dari berbagai pihak yang memiliki kepentingan dengan informasi-informasi tersebut. Menurut Dewi \& Sitinjak(2019) keputusan investasi para investor akan berubah jika informasi-informasi yang diberikan perusahaan dapat mudah dimengerti.

Menurut Maryanti \& Fithri (2017) menyatakan bahwa kepercayaan masyarakat terutama investor meningkat saat perusahaan tersebut memperhatikan lingkungan sosial. Investor semakin meningkat kepercayaannya kepada perusahaan yang diikuti dengan meningkatnya likuiditas saham perusahaan (Jiambalvo, 1996) dan biaya modal mengalami penurunan (Botosan, 1997). Maka dapat diharapkan berdampak terhadap nilai perusahaan (Titi, Sabar, \& Sixpria Nedsal, 2011).

Definsi pengungkapan adalah suatu unsur dari mekanisme transparansi terhadap informasi yang dikeluarkan dan tidak dirahasiakan. Menurut Suwardjono (2005)ada dua tujuan diadakannya pengungkapan antara lain: 1 . Dipandang mampu memberikan dan menyajikan transparansi informasi sehingga tujuan yang diperoleh dalam pelaporan keuangan dapat tercapai, 2.Memberikan pelayanan kepada beberapa pihak yang memiliki kepentingan berbeda satu sama lain.Pengungkapan yang ada pada laporan tanggung jawab sosial perusahaan adalah suatu informasi berbentuk laporan yang ditujukan kepada stakeholder dengan tujuan agar terwujudnya transparansi dalam segala aktfitas yang dilakukan oleh perusahaan khususnya aktifitas lingkungan. 


\section{sosio e-kons}

Volume 11, No. 3, Desember 2019, pp. 249-258

e-ISSN: $2502-5449$

p-ISSN: 2085-2266

DOI : $10.30998 /$ sosioekons.v11i3.5084

Penelitian ini bertujuan untuk pengaruh Tata Kelola Perusahaan Terhadap Pengungkapan Tanggung Jawab Sosial, Pengungkapan Tanggung Jawab Sosial Terhadap Nilai Perusahaan dan pengaruh tidak langsung Tata Kelola Perusahaan pada Nilai Perusahaan melalui Pengungkapan Tanggung Jawab Sosial pada perusahaan batu bara yang terdaftar di Bursa Efek Indonesia.

Penelitian ini diharapkan mampu memberikan manfaat dari segi teoritis dan aplikatif. Manfaat teoritis penelitian ini adalah mampu memberikan bukti secara empiris dan metodologi bagi akademisi dan peneliti lainnya. Manfaat implementasi dari penelitian ini adalah mampu memberikan manfaat pada ilmu pengetahuan megenai pengungkapan tanggung jawab sosial yang mampu memberikan manfaat bagi manajemen akan pentingnya investasi jangka panjang bagi perusahaan yang terdaftar di Bursa Efek Indonesia.

Kajian Teori

1. Teori agensi merupakan teori yang menjelaskan mengenai konflik yang terjadi di perusahaan antara para peinsipal dengan manajemen perusahaan (Jensen \& Meckling, 1976). Teori agensi memiliki sebuah pandangan yang disebut dengan nexus of contract atau disebut dengan komitmen antara perusahaan dengan stakeholder dengan sebuah komtrak yang mengikat kedua belah pihak (Rustiarini, 2011).

2. Teori legitimasi merupakan teori yang mendasari organisasi usaha untuk membrikan informasi tanggung jawab sosial perusahaan secara sukarela(Lu \& Abeysekera, 2014). Menurut (Suchman, 1995)legitimasi adalah sebuah asumsi umum dalam suatu tindakan yang dilakukan perusahaan dapat dikatakan layak dan tidak jauh dari norma-norma yang ada di masyarakat.

3. Teori stakeholder merupakan teori yang berasumsi segala kegiatan yang dilakukan perusahaan ditentukan oleh para stakeholder. MenurutLindawati \& Puspita(2015) Teori stakeholder merupakan suatu teori yang menyatakan bahwa keberlangsungan suatu organisasi usaha tidak terlepas dari ikut campurnya peran dari para stakeholder.

4. Dewan komisaris Independen merupakan unsur yang ada didalam perusahan dan memiliki tugas dalam pengontrolan serta pengawasan terhadap aktifitas perusahaan yang dijlankan oleh direksi. Sedangkan komisaris independen diharapkan mampu menjadi penyeimbang dalam bersikap netral terhadap kebijakan-kebijakan yang dikeluarkan oleh para direksi.Pasal 20 pada aturan Otoritas Jasa Keuangan bernomer 33/POJK 04/2014 menerangkan banyaknya komisaris independen pada perusahaan publik.

5. Kepemilikan Asing adalah penguasaan saham di perusahaan yang dimiliki oleh perseorangan atau perseroan terbatas asing dengan ketentuan sesuai aturan hukum yang berlaku. Wirawan(2013)menyatakan bahwa pemilik asing adalah komponen karakteristik tata kelola perusahaan yang mampu berpengaruh pada pengungkapan tanggung jawab sosial perusahaan.

6. Kepemilikan Publik adalah kepemilikan yang dimiliki oleh individu atau intitusi dengan kepemilikan saham dibawah lima persen yang tidak memiliki afilisi dengan manajemen atau perusahaan (Rozak, 2012). Menurut Badjuri(2011)perusahaan dengan kepemilikan saham publik menunjukkan bahwa organisasi tesebut memiliki kredibilitas yang baik dimata investor luas dalam memberikan kepastian mengenai pembagian keuntungan kepada investor secara layak dan berlanjut terus menerus sehingga dapat dikatakan perusahan tersebut akan cenderung memiliki fokus terhadap mengungkapkan kegiatan sosialnya.

7. Komite Audit Berdasarkan keputusan yang termuat dalam surat edaran ketua Otoritas Jasa Keuangan No kep-29/PM/2004 menjelaskan bahwa satuan komite audit merupakan satuan yang disusun oleh dewan komisaris perusahaan bertujuan untuk menjadi pelaksana fungsi dalam memberikan informasi bagi dewan komisaris. Keberadaan komite audit mampu diterima sebagai salah satu unsur dalam tercapainya kinerja tata kelola perusahaan. Bahkan adanya komite audit yang efektif mampu melaksanakan salah satu aspek dalam memberikan penilaian pelaksanaan Tata kelola perusahaan dengan baik 


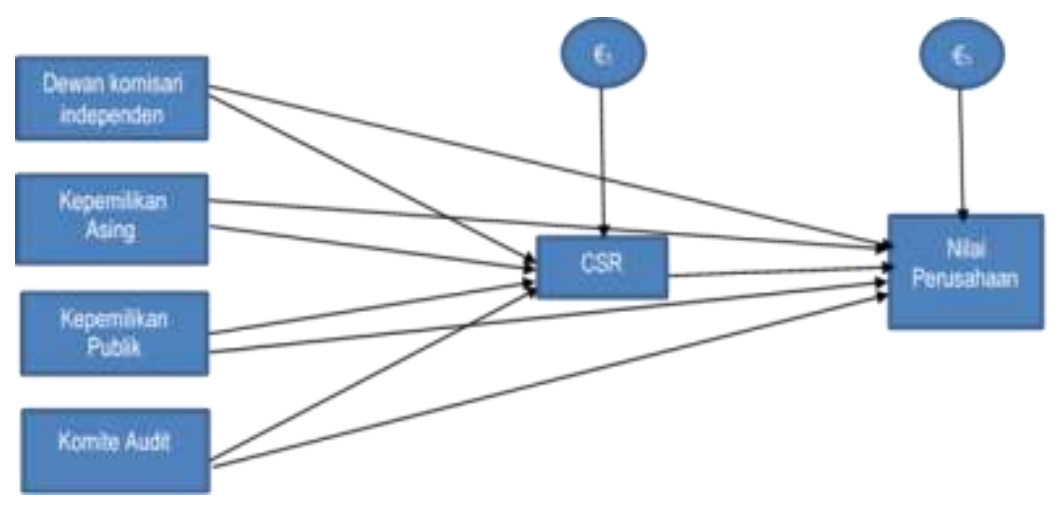

\section{Hipotesis}

H1 : Dewan komisaris independen berpengaruh positif terhadap tanggung jawab sosial perusahaan

H2 : Kepemilikan saham Asing berpengaruh positif terhadap tanggung jawab sosial perusahaan

H3 : Kepemilikan saham publik berpengaruh positif terhadap tanggung jawab sosial perusahaan

H4 : Komite audit berpengaruh positif terhadap tanggung jawab sosial perusahaan

H5 : Dewan Komisaris berpengaruh positif terhadap Nilai perusahaan

H6 : Kepemilikan saham Asing berpengaruh positif terhadap nilai perusahaan

H7 : Kepemilikan Saham Publik berpengaruh positif terhadap nilai perusahaan

H8 : Komite Audit berpengaruh positif terhadap nilai perusahaan

H9 : tanggung jawab sosial perusahaan berpengaruh positif terhadap nilai perusahaan

H10 : terdapat pengaruh antara dewan komisaris dan nilai perusahaan melalui tanggung jawab sosial perusahaan

H11 : terdapat pengaruh antara Kepemilikan saham asing dan nilai perusahaan melalui tanggung jawab sosial perusahaan

H12 : terdapat pengaruh antara Kepemilikan saham publik dan nilai perusahaan melalui tanggung jawab sosial perusahaan

H13 : terdapat pengaruh antara komite audit dan nilai perusahaan melalui tanggung jawab sosial perusahaan

\section{METODE}

Metode penelitian yang digunakan adalah metode deskriptif dan verifikatif, populasi penelitian ini adalah seluruh perusahaan batu bara yang terdaftar di Bursa Efek Indonesia periode 2013-2018. Metode penentuan sampel dilakukan dengan metode purposive sampling dan diperoleh sampel sebanyak 7 perusahaan dengan 55 perusahaan.Variabel penelitian yang digunakan dewan komisaris independen, kepemilikan saham asing, kepemilikan saham publik,komite audit, pengungkapan tanggung jawab sosial, nilai perusahaan.Penelitian ini menggambarkan pola hubungan yang mengungkapkan pengaruh variabel independen terhadap variabel dependen,baik secara langsung maupun tidak langsung melalui variabel lain. Pola hubungan yang semacam ini dapat dianalisis dengan Path analysis, dengan rancangan model sebagai berikut : 
Sub-Struktural I (Hubungan $\mathrm{X}_{1}, \mathrm{X}_{2}, \mathrm{X}_{3}$, dan $\mathrm{X}_{4}$ terhadap $\mathrm{Y}$ )

$Y=\beta_{1} X_{1}+\beta_{2} X_{2}+\beta_{3} X_{3}+\beta_{4} X_{4}+\varepsilon_{1}$

Sub-Struktural II (Hubungan $X_{1}, X_{2}, X_{3}, X_{4}, Y$ terhadap $Z$ )

$Z=\beta_{1} X_{1}+\beta_{2} X_{2}+\beta_{3} X_{3}+\beta_{4} X_{4}+Y+\varepsilon_{1}$

Tingkat signifkansi dalam penelitian ini yaitu $\alpha=5 \%$ dengan kriteria pengujian sebagai berikut

$: \mathrm{H}_{0}$ diterima jika $\mathrm{t}_{\text {hitung }} \leq \mathrm{t}_{\text {abel }}, \mathrm{H}_{0}$ ditolak jika $\mathrm{t}_{\text {hitung }}>\mathrm{t}_{\text {abel }}$

\section{HASIL DAN PEMBAHASAN}

\section{HASIL}

Hasil pengujian melalui Uji Asumsi Klasik sudah memenuhi, Pemilihan Model dari kedua sub-strural pada common effect dan Regresi Panel Data, adapun hasil sebagai berikut :

Sub-Struktural I (Hubungan $X_{1}, X_{2}, X_{3}$, dan $X_{4}$ terhadap $Y$ )

Tabel 1. Hasil Estimasi Common Effect

\begin{tabular}{lrrrc}
\hline Variable & Coefficient & Std. Error & t-Statistik & Prob. \\
\hline C & 0.592120 & 0.032901 & 6.296537 & 0.0000 \\
\hline DKI & 0.192100 & 0.109213 & 3.290122 & 0.0000 \\
\hline KA & 0.258101 & 0.049121 & 2.981211 & 0.0000 \\
\hline KSP & 0.210211 & 0.042901 & 2.421334 & 0.0009 \\
\hline KAU & 0.313243 & 0.034912 & 2.690153 & 0.0003 \\
\hline
\end{tabular}

Sumber : Output Eviews 9.0

Sub-Struktural II (Hubungan $\mathbf{X}_{1}, \mathbf{X}_{2}, \mathbf{X}_{3}, \mathbf{X}_{4}, \mathbf{Y}$ terhadap Z)

Tabel 2. Hasil Estimasi Common Effect

\begin{tabular}{ccccc}
\hline Variable & Coefficient & Std. Error & t-Statistik & Prob. \\
\hline C & 0.476912 & 0.038121 & 8.542121 & 0.0000 \\
\hline DKI & 0.609121 & 0.391210 & 0.992121 & 0.3796 \\
\hline KA & 0.301230 & 0.056341 & 3.872131 & 0.0013 \\
\hline KSP & 0.167129 & 0.020123 & 3.498235 & 0.0003 \\
\hline KAU & 0.365101 & 0.044981 & 0.769321 & 0.6213 \\
\hline CSR & 0.501128 & 0.058120 & 3.609712 & 0.0006 \\
\hline
\end{tabular}

Sumber: Output Eviews 9.0

Tabel 3. Hasil Ringkasan Koefisien Jalur Pengaruh Langsung

\begin{tabular}{ccccc}
\hline Regresi & Koefisien Reg & Std Error & Prob & Keterangan \\
\hline DKI --- CSR & 0.192100 & 0.109213 & 0.0000 & Signifikan \\
\hline KA --- CSR & 0.258101 & 0.049121 & 0.0000 & Signifikan \\
\hline KSP --- CSR & 0.210211 & 0.042901 & 0.0009 & Signifikan \\
\hline KAU --- CSR & 0.313243 & 0.034912 & 0.0003 & Signifikan \\
\hline DKI --- NP & 0.609121 & 0.391210 & 0.3796 & Tidak Signifikan \\
\hline KA --- NP & 0.301230 & 0.056341 & 0.0013 & Signifikan \\
\hline KSP --- NP & 0.167129 & 0.020123 & 0.0003 & Signifikan \\
\hline KAU --- NP & 0.365101 & 0.044981 & 0.6213 & Tidak Signifikan \\
\hline CSR --- NP & 0.501128 & 0.058120 & 0.0006 & Signifikan \\
\hline
\end{tabular}

Sumber : Output Eviews 9.0 


\section{Dewan komisaris independen berpengaruh positif terhadap tanggung jawab sosial perusahaan}

Hasil statistik yang diperoleh menyatakan bahwa dewan komisaris independen memiliki pengaruh positif terhadap pengungkapan tanggung jawab sosial perusahaan. Temuan ini mendukung teori stakeholder yang menyatakan dewan komisaris cenderung mendorong perusahaan untuk mengungkapkan informasi secara jelas kepeda para pemangku kepentingan salah satunya informasi dalam mengungkapkan tanggung jawab sosial perusahaan. Temuan tersebut menandakan bahwa perusahaan telah menjalankan peraturan otoritas jasa keuangan bernomer 33/POJK 04/2014 yang mengatur banyaknya dewan komisaris khususnya dewan komisaris independen sebagai penyeimbang pada setiap keputusan perusahaan. Hasil ini juga konsisten dengan penelitian (Álvarez \& Zubeltzu, 2017; Isa \& Muhammad, 2014).

\section{Kepemilikan saham asing berpengaruh positif terhadap tanggung jawab sosial perusahaan}

Hasil statistik yang diperoleh menyatakan bahwa kepemilikan saham asing memiliki pengaruh positif terhadap pengungkapan tanggung jawab sosial perusahaan. Temuan ini mendukung teori agensi yang menyatakan bahwa kepemilikan saham asing mampu menjadi suatu pengawas terhadap proses aktivitas perusahaan yang berjalan sehingga para manajemen mendapatkan informasi yang cukup baik untuk dilaporkan kepada para stakeholder. Secara umum dari hasil tersebut dapat dilihat kepemilikan saham asing dapat turut andil dalam isu-isu sosial yang ada di Indonesia. Hasil ini konsiten dengan penelitian dari (Dewi \& Suaryana, 2015; Julia, 2017; Rustiarini, 2011).

\section{Kepemilikan saham publik berpengaruh positif terhadap tanggung jawab sosial perusahaan}

Hasil statistik yang diperoleh menyatakan bahwa kepemilikan saham publik memiliki pengaruh positif terhadap pengungkapan tanggung jawab sosial perusahaan. Temuan tersebut mendukung teori stakeholder yang menyatakan bahwa kepemilikan saham oleh publik akan memberikan dampak yang besar terhadap pengungkapan tanggung jawab sosial perusahaan. Entitas usaha dengan kepemilikan saham publik memiliki kepercayaan yang besar dari publik sendiri sehingga entitas tersebut berusaha semaksimal mungkin untuk menjaga kepercayaan dengan aktif dalam mengungkapan kegiatannya salah satunya lingkungan sosial. Hasil ini konsisten dengan penelitian dari (Ayu \& Harta, 2013; Rahayu \& Anisyukurlillah, 2015).

\section{Komite audit berpengaruh positif terhadap tanggung jawab sosial perusahaan}

Hasil statistik yang diperoleh menyatakan bahwa komite audit memiliki pengaruh positif terhadap pengungkapan tanggung jawab sosial perusahaan. Temuan tersebut mendukung teri keagenan yang menyatakan bahwa komite audit yang dibentuk oleh perusahaan sebagai unsur yang dapat sebagai penghubung antara manajemen dan para stakeholder perusahaan baik dalam maupun luar perusahaan. Komite audit sangat penting bagi perusahaan dalam sistem pengawasan yang ada di perusahaan dengan semakin banyaknya intensitas rapat komite audit memberikan dampak yang positif terhadap segala bentuk pengawasan aktifitas perusahaan, salah satunya adalah aktifitas dalam mengungkapkan tanggung jawab sosial perusahaan. Hasil ini konsisten dengan penelitian dari (Laksmi \& Kamila, 2018; Suryono \& Prastiwi, 2011; Tommy et al., 2015). 


\section{Dewan Komisaris berpengaruh positif terhadap Nilai perusahaan}

Hasil statistik yang diperoleh menyatakan bahwa dewan komisaris independen tidak memiliki pengaruh secara langsung terhadap nilai perusahaan. Temuan tersebut mengindikasikan bahwa dewan komisaris tidak efektif dalam meningkatkan niai perusahaan, kemungkinan yang terjadi dilapangan adalah dewan komisaris masih sedikit sehingga ketidakefektifan tersebut terjadi. Padahal menurut Titi et al., (2011) entitas usaha yang memeiliki komisaris independen dengan kuantitas banyak akan berdampak pada kinerja yang bagus salah satunya nilai perusahaan. Hasil ini konsisten dengan penelitian dari (Siallagan \& Machfoedz, 2006).

\section{Kepemilikan saham Asing berpengaruh positif terhadap nilai perusahaan}

Hasil statistik yang diperoleh menyatakan bahwa kepemilikan saham asing memiliki pengaruh secara langsung terhadap nilai perusahaan. Temuan ini mendukung Teori stakeholder yang mengartikan bahwa entitas usaha adalah satu kesatuan organisasi yang saling terhubung dengan kepentingan para stakeholder. Temuan tersebut mengindikasikan para pemegang saham asing sangat nyaman untuk berinvestasi dan berusaha semaksimal mungkin untuk memberikan pengaruh terhadap keaikan nilai perusahaan. Hasil ini konsisten dengan penelitian dari Sujoko (2017).

\section{Kepemilikan Saham Publik berpengaruh positif terhadap nilai perusahaan}

Hasil statistik yang diperoleh menyatakan bahwa kepemilikan saham publik memiliki pengaruh secara langsung terhadap nilai perusahaan. Artinya ketika saham perusahaan yang dimiliki oleh publik maka perusahaan akan dituntut untuk meningkatkan kinerja perusahaannya baik secara kinerja sosial maupun keuangan, sehingga perusahaan harus meningkatkan citra dengan melakukan peningkatan dalam segala aktivitasnya dan akan berdampak pada nilai perusahaan tersebut semakin meningkat. Hasil ini konsisten dengan penelitian dari (Adnantara, 2014).

\section{Komite Audit berpengaruh positif terhadap nilai perusahaan}

Hasil statistik yang diperoleh menyatakan bahwa komite audit memiliki pengaruh tidak langsung terhadap nilai perusahaan. Temuan tersebut tidak mendukung teori keagenan yang menyatakan bahwa komite audit merupakan unsur yang mampu menyelesaikan masalahmasalah agensi yang ada di perusahaan. Menurut Hamzah (2016) unsur komite audit yang berasal dari luar dapat melindungi kepentingan-kepentingan para pemegang saham sehingga meminimalisir kecurangan yang ada. Posisi komite audit merupakan unsur dari pembentukan laporan keuangan sehingga memiliki dampak terhadap peningkatan nilai perusahaan. Hasil ini konsisten dengan penelitian dari (Handayani, 2017; Rupilu, 2011).

\section{Tanggung jawab sosial perusahaan berpengaruh positif terhadap nilai perusahaan}

Hasil statistik yang diperoleh menyatakan bahwa tanggung jawab sosial perusahaan memiliki pengaruh positif terhadap nilai perusahaan.temuan tersebut mendukung teori legitimasi yang menyatakan bahwa suatu keadaan suatu system nilai perusahaan ssama dengan system sosial yang berdamapak kepercayaan para investor karena perusahaan telah melakukan aktivitas sosial sehingga mendapatkan legitimasinya di masyarakat sekitar. Temuan tersebut juga mengingikasikan bahwa para investor bahwa para investor memberika respon yang positif bagi perusahaan yang mengungkapkan tanggung jawab sosial perusahaan sehingga berdampak pada peningkatan nilai investasi yang mengakibatkan nilai perusahaan semakin meningkat pula. Hasil ini konsisten dengan penelitian dari (Adnantara, 2014). 


\section{Terdapat pengaruh tata kelola perusahaan dan tanggung jawab sosial perusahaan pada} nilai perusahaan

Berdasarkan hasil statistik analisis jalur, dapat dilihat terdapat pengaruh tidak langsung variabel tata kelola perusahaan yaitu dewan komisaris independen dan komite audit terhadap nilai perusahaan artinya hal ini menunjukan bahwa variabel pengungkapan tanggung jawab sosial perusahaan tidak mampu memediasi nilai perusahaan. Sedangkan terdapat pengaruh langsung untuk variabel tata kelola perusahaan yaitu kepemilikan asing dan kepemilikan publik terhadap nilai perusahaan, artinya hal ini menunjukan bahwa variabel pengungkapan tanggung jawab sosial perusahaan mampu memediasi nilai perusahaan.

\section{SIMPULAN}

Simpulan yang dapat ditarik dari penelitian ini adalah Dewan Komisaris Independen, Kepemilikan Saham Asing, Kepemilikan Saham Publik dan Komite Audit memiliki pengaruh positif terhadap Pengungkapan Tanggung Jawab Sosial, Pengungkapan Tanggung Jawab Sosial memiliki pengaruh positif terhadap nilai perusahaan, dan secara langsung Dewan Komisaris Independen, Komite Audit memiliki pengaruh tidak langsung terhadap nilai perusahaan melalui pengungkapan tanggung jawab sosial, dan Kepemilikan Saham Asing dan Kepemilikan Saham Publik tidak berpengaruh tidak langusng pada nilai perusahaan melalui pengungkapan tanggung jawab sosial. Implikasi yang dapat diambil dari penelitian ini diharapkan perusahaan sektor pertambangan batu bara diharapkan mampu memberikan fokus terhadap isu lingkungan dan sosial. Pada pengembangan penelitian selanjutnya diharapkan menambah variabel-variabel yang mempengaruh pengungkapan tanggung jawab sosial perusahaan, peneliti berharap penelitian mendatang juga menggunakan sampel seluruh perusahaan yang terindeks di Bursa Efek Indonesia.

\section{DAFTAR RUJUKAN}

Adnantara, K. (2014). Pengaruh Struktur Kepemilikan Saham Dan Corporate Social Responsibility Pada Nilai Perusahaan. Buletin Studi Ekonomi, 18(2), 107-113.

Álvarez, I., \& Zubeltzu, E. (2017). Firms' Board Independence and Corporate Social Performance: A Meta-Analysis. Sustainability, 9(6), 1006.

Ayu, G., Wiwik, P., Putu, N., \& Harta, S. (2013). Pengaruh Karakteristik Perusahaan Terhadap Corporate Social Responsibility Disclosure. E-Jurnal Akuntansi, 5(2), 326344.

Badjuri, A. (2011). Faktor-Faktor Fundamental, Mekanisme Coorporate Governance, Pengungkapan Cooporate Social Responsibility (CSR) Perusahaan Manufaktru dan Sumber Daya Alam di Indonesia. Dinamika Keuangan Dan Perbankan, 3(1), 38-54.

Botosan, C. A. (1997). Disclosure level and the cost of equity capital. Accounting Review, 72(3), 323-349.

Dewi, N. P. M. S., \& Suaryana, I. G. N. A. (2015). Pengaruh Profitabilitas dan Kepemilikan Asing Pada Pengungkapan Corporate Social Responsibility. E-Jurnal Akuntansi Universitas Udayana, 13(1), 84-98.

Dewi, R. K., \& Widagdo, B. (2012). Pengaruh Corporate Social Responsibility Dan Good Corporate Governance Terhadap Nilai Perusahaan (Studi Pada Sektor Pertambangan Di Bursa Efek Indonesia). Keberlanjutan, 2(1), 498.

Dewi, R. R., \& Sitinjak, M. (2019). Analisis Pengaruh Karakteristik Perusahaan Terhadap Earning Response Coeficient Dengan Corporate Social Responsibility Sebagai 
Variabel Intervening Pada Perusahaan Manufaktur Yang Terdaftar Di Bursa Efek I ndonesia. Jurnal Informasi, Perpajakan, Akuntansi, Dan Keuangan Publik, 4(2), 149.

Hamzah, A. (2016). Pengungkapan Tanggung Jawab Sosial Perusahaan Pada Sektor Keuangan Di Bursa Efek Indonesia. Jurnal Riset Keuangan Dan Akuntansi, 2(2).

Handayani, B. D. (2017). Mekanisme Corporate Governance, Enterprise Risk Management, Dan Nilai Perusahaan Perbankan. Jurnal Keuangan Dan Perbankan, $\quad$ 21(1), 70-81.

Isa, M. A., \& Muhammad, S. (2014). The Impact of Board Characteristics on Corporate Social Responsibility Disclosure: Evidence from Nigerian Food Product Firms. International Journal of Management Science and Business Administration, 1(12), 34-45.

Jensen, M. C., \& Meckling, W. H. (1976). Theory of the firm: Managerial behavior, agency costs and ownership structure. Journal of Financial Economics, 3(4), 305-360.

Jiambalvo, J. (1996). Discussion of "causes and consequences of earnings manipulation: An analysis of firms subject to enforcement actions by the SEC." Contemporary Accounting Research, 13(1), 37-47.

Julia, J. (2017). pengaruh Struktur Kepemilikan, Pelanggan Dan Slack Organisasi Terhadap Pengungkapan Tanggungjawab Sosial Perusahaan (Studi Empiris Pada Perbankan Indonesia Yang Terdaftar Di Bei Tahun 2013-2015). Accounthink, 2(02), 349-361.

Laksmi, A. C., \& Kamila, Z. (2018). The Effect of Good Corporate Governance and Earnings Management to Corporate SOCIAL RESPONSIBILITY DISCLOSURE. Academy of Accounting and Financial Studies Journal, 22(1), 1-16.

Lindawati, A. S. L., \& Puspita, M. E. (2015). Corporate Social Responsibility: Implikasi Stakeholder dan Legitimacy Gap dalam Peningkatan Kinerja Perusahaan. Jurnal Akuntansi Multiparadigma, 157-174.

Lu, Y., \& Abeysekera, I. (2014). Stakeholders' power, corporate characteristics, and social and environmental disclosure: Evidence from China. Journal of Cleaner Production, 64, 426-436.

Maryanti, E., \& Fithri, W. N. (2017). Corporate Social Responsibilty, Good Corporate Governance, Kinerja Lingkungan Terhadap Kinerja Keuangan Dan Pengaruhnya Pada Nilai Perusahaan. Journal of Accounting Science, 1(1), 21.

Rahayu, P., \& Anisyukurlillah, I. (2015). Pengaruh Kepemilikan Saham Publik, Profitabilitas Dan Media Terhadap Pengungkapan Tanggung Jawab Sosial. Accounting Analysis Journal, 4(3), 1-9.

Rozak, A. (2012). Pengaruh Tingkat Profitabilitas, Ukuran Perusahaan, Kepemilikan Saham Oleh Publik, Leverage Dan Kelompok Industri Terhadap Tingkat Internet Financial Reporting (IFR). 6(2), 101-112.

Rupilu, W. (2011). Pengaruh Mekanisme Corporate Governance terhadap Kualitas Laba dan Nilai Perusahaan pada Perusahaan Manufaktur yang Terdaftar di Bursa Efek Indonesia. Jurnal Akuntansi, Manajemen Bisnis, Dan Sektor Publik, 8(1), 101-127.

Rustiarini, N. W. (2011). Pengaruh Struktur Kepemilikan Saham Pada Pengungkapan Corporate Social Responsibility. Jurnal Ilmiah Akuntansi Dan Bisnis, 6(1), 1-24.

Saputra, M. (2010). PENGARUH CORPORATE GOVERNANCE TERHADAP NILAI PERUSAHAAN DI BURSA EFEK INDONESIA, JAKARTA. Journal of Indonesian Applied Economics, 4(1), 81-92.

Suchman, M. C. (1995), and Strategic Managing Legitimacy: Approaches. Academy of Management Review, 20(3), 571-610.

Suryono, H., \& Prastiwi, A. (2011). Pengaruh Karakteristik Perusahaan dan Corporate Governance Terhadap Praktik Pengungkapan Sustainability Report (SR): Studi pada Perusahaan-Perusahaan yang Listed (Go-Public) di Bursa Efek Indonesia (BEI) periode 2007-2009. Simposium Nasional Akuntansi XIV Aceh 2011, 21-22. 


\section{sosio e-kons}

Volume 11, No. 3, Desember 2019, pp. 249-258

e-ISSN: 2502-5449

p-ISSN: 2085-2266

DOI : $10.30998 /$ sosioekons.v11i3.5084

Suwardjono. (2005). Teori Akuntansi: Perekayasaan Pelaporan Keuangan (3, ed.). Yogyakarta: BPFE.

Titi, S., Sabar, W., \& Sixpria Nedsal. (2011). Pengaruh Pengungkapan Tanggung Jawab Sosial dan Praktik Tata Kelola Perusahaan terhadap Nilai Perusahaan. Jurnal Ekonomi Dan Bisnis, 10(2), 95-105.

Tommy, Y. V., Utary, A. R., \& Oktavianti, B. (2015). Pengaruh Implementasi Good Corporate Governance Terhadap Pengungkapan Informasi Tanggung Jawab Sosial. Jurnal Akuntansi, (c), 427-436.

Wirawan, N. B. (2013). Karakteristik GCG terhadap pengungkapan TSP pada perusahaan manufaktur yang terdaftar di Bursa Efek Indonesia tahun 2010-2011. Jurnal Profita, 45(05), 180-200. 